\title{
Phenotypic characterization of Plasmodium berghei responsive CD8+ T cells after immunization with live sporozoites under chloroquine cover
}

\author{
Clara Brando ${ }^{1,2}$, Jason H Richardson², Jittawadee Murphy², Christian F Ockenhouse ${ }^{1}$ and Edwin Kamau ${ }^{*}$
}

\begin{abstract}
Background: An effective malaria vaccine remains elusive. The most effective experimental vaccines confer only limited and short-lived protection despite production of protective antibodies. However, immunization with irradiated sporozoites, or with live sporozoites under chloroquine cover, has resulted in long-term protection apparently due to the generation of protective CD8+ T cells. The nature and function of these protective CD8+ $T$ cells has not been elucidated. In the current study, the phenotype of CD8+ T cells generated after immunization of C57BL/6 mice with live Plasmodium berghei sporozoites under chloroquine cover was investigated.
\end{abstract}

Methods: Female C57BL/6 mice, C57BL/6 mice B2 macroglobulin -/- [KO], or invariant chain-/- [lc KO] [6-8 weeks old] were immunized with $P$. berghei sporozoites and treated daily with $800 \mu \mathrm{g} / \mathrm{mouse}$ of chloroquine for nine days. This procedure of immunization is referred to as "infection/cure". Mice were challenged by inoculating intravenously 1,000 infectious sporozoites. Appearance of parasitaemia was monitored by Giemsa-stained blood smears.

Results: By use of MHC I and MHC II deficient animals, results indicate that CD8+ T cells are necessary for full protection and that production of protective antibodies is either CD4+ T helper cells dependent and/or lymphokines produced by CD4 cells contribute to the protection directly or by helping CD8+ T cells. Further, the phenotype of infection/cure $P$. berghei responsive $C D 8+T$ cells was determined to be $K L R G 1^{\text {high }} C D 27^{\text {low }} C D 44^{\text {high }}$ and $C D 62 L^{\text {low }}$.

Conclusion: The KLRG1 ${ }^{\text {high }} \mathrm{CD} 27^{\text {low }} \mathrm{CD} 44^{\text {high }}$ and CD62 $\mathrm{L}^{\text {low }}$ phenotype of CD8+ T cells is associated with protection and should be investigated further as a candidate correlate of protection.

\section{Background}

While reduction in malaria cases has been reported in many countries, malaria remains among the world's most prevalent and fatal infectious disease. In 2011, it was estimated there were 216 million malaria episodes and 655,000 malaria deaths [1]. With the majority of the deaths occurring in children less than five years of age, and with almost half of the world population at risk, an effective vaccine against malaria is urgently needed [2].

Natural exposures to malaria infections do not immediately induce immunity leaving infants and young children

\footnotetext{
* Correspondence: edwin.kamau@us.army.mil

'Military Malaria Research Program, Malaria Vaccine Branch, Walter Reed Army Institute of Research, 503 Robert Grant Ave, Silver Spring, MD 20910 USA

Full list of author information is available at the end of the article
}

in endemic areas susceptible to multiple episodes of the disease. Eventually, partial immunity is acquired in older children and adults, affording them protection against clinical symptoms and/or severe disease. However, protection is not sterile [3] and the immune responses to Plasmodium parasites are short-lived [4]. This is attributed to short halflife of protective antibodies [4] and to a cellular response [5-7] too weak to grant protection [8-11]. Sterile protection has however been achieved experimentally in both animal models of malaria and in malaria-naive humans immunized with whole live sporozoites [12].

Intravenous administration of irradiated sporozoites renders long-lasting protection [13-17] by a mechanism mediated largely by $\mathrm{CD} 8+\mathrm{T}$ cells [18-23]. Although there is data in favour of other mechanisms [24] and different mice strains show different susceptibility to malaria $[25,26]$, 
$\mathrm{CD} 8+\mathrm{T}$ cell remain the main player in this model of protection. Evidence of protection conferred by immunization with sporozoites under chloroquine (CQ) cover was initially demonstrated in mice and rats using Plasmodium berghei $[27,28]$. More recently, infection under CQ cover has also been shown to induce long-lasting protection in malaria-naive human $[29,30]$ and murine models [31,32]. In these models, CD8+ T cells appear to play an important role in protection [24,29-32]. Taken together, these data suggest that while natural exposure elicits weakly protective humoral and cellular immunity, strategies such as inoculation of irradiated sporozoites or viable sporozoites under CQ cover induce CD8+ T cells which, alone or in combination with antibodies, provide long-lasting protection. A better understanding of the mechanics of these protective cells is fundamental to vaccine development efforts.

In this study, P. berghei murine model was used to characterize the phenotype of CD8 $+\mathrm{T}$ cells generated under CQ cover and to associate these phenotypes with protection from a lethal challenge.

\section{Methods \\ Mice}

Female C57BL/6 mice, C57BL/6 mice B2 macroglobulin -/- (KO), or invariant chain-/- (Ic KO) (6-8 weeks old) were purchased from the Jackson Laboratory (Bar Harbor, ME). These animals were housed at the Walter Reed Army Institute of Research (WRAIR) animal facility and handled according to institutional guidelines. All procedures were reviewed and approved by the WRAIR Animal Care and Use Committee (IACUC) and were performed in a facility accredited by the Association for Assessment and Accreditation of Laboratory Animal Care International. Euthanasia methods were compliant with the approved IACUC proto$\mathrm{col}$, with frequent supervision by the institute's veterinary team. After the animals were challenged, strict humane endpoints criteria were adhered to by frequently monitoring the health of the animals in order to avoid or terminate unrelieved pain and/or distress. Animals positive for parasitaemia for two consecutive days were euthanized before showing distress and/or pain by inhalation of $\mathrm{CO}_{2}$ from a pressurized tank in a chamber. This was followed by cervical dislocation prior to disposal of the dead mice.

\section{Sporozoites}

Sporozoites (Spz) from P. berghei ANKA strain were extracted from salivary glands of Anopheles stephensi mosquitoes 16-21 days post blood meal as previously described [19]. Mosquitoes were maintained in the WRAIR Entomology Branch Insectary facilities.

\section{Reagents, antibodies and chemicals}

Cell media and CFSE were purchased from Life Technologies (Carlsbad, CA). Purified antibodies or fluorochrome labeled antibodies were purchased from eBioscience (San Diego, CA). Brefeldine A, Giemsa stain and CQ were purchased from Sigma (St. Louis, MO).

\section{Immunization and treatment}

Experimental animals were inoculated two or three times intravenously with 10,000 or $20,000 \mathrm{Spz}$ (in $100 \mathrm{ul} \mathrm{PBS}$ ), ten days apart and treated daily with $800 \mu \mathrm{g} /$ mouse (100 ul in PBS) of CQ, administered intraperitoneally (i.p.), starting from the day of the first inoculation until nine days post last inoculation. This procedure of immunization is referred to as "infection/cure". For the CQ control group, the same regimen of CQ as that of the experimental group was administered with the exception that these animals were not inoculated with Spz. The absolute control group received PBS only.

\section{Challenge and assessment of protection}

For challenge experiments, mice were inoculated intravenously with 1000 infectious Spz. Challenge was performed at two weeks post suspension of CQ treatment. Appearance of parasitaemia was monitored by Giemsastained blood smears. Animals free of parasitaemia for two weeks were considered protected.

\section{Lymphocyte preparation}

Mice were euthanized by $\mathrm{CO}_{2}$ inhalation as described above. Livers and spleens were removed, and livers were perfused with $10 \mathrm{ml}$ PBS. Single cell suspensions of lymphocytes were made from both organs (liver infiltrating lymphocytes and splenocytes). Cells were re-suspended in PBS and used for analysis or transfer. Peripheral blood for blood lymphocyte analysis was collected from the tail vein in a heparinized vial.

\section{Serum and splenocyte transfer}

Recipient mice in transfer experiments received either $500 \mu \mathrm{L} /$ mouse of undiluted serum intraperitoneally, $20 \times 10^{\wedge} 6$ splenocytes re-suspended in $500 \mu \mathrm{L}$ of PBS by injection into the tail vein, or a combination of both.

\section{Flow cytometry analysis}

Analysis was performed with an LSR II cytometer (Beckon Dickinson San Diego, CA) and data were analysed with Flow-Jo software (BD). The panel of fluorochrome conjugated antibodies for flow cytometry included: CD3- PrcP, CD4-Pacific Blue, CD8-V500 or Pacific Orange, CD45RB or CD44- Alexa fluoro -700, CD27-APC, CD127 -PE, KLRG-1 FITC. When the intracellular cytokine IFN $\gamma$ was tested, the panel used was: CD8-PO, KLRG-1-FITC, CD62-PrCPcy5.5, CD44 Alexa-700, CD27-APC, IFN- $\gamma$-PE. In all assays UVviability dye was included. Flow cytometry antibodies were purchased from Life Technologies (Carlsbad, CA). 


\section{Abbreviation for fluorochrome}

Allophycocyanin (APC), Pyridine-chlorophyll proteinsCy-5 (PrCP-Cy5), Phycoerythrin (PE), Fluorescein (FITC). Antibodies are indicated by the marker recognizedfluorochrome, e.g. anti CD3 Fluorescein-conjugated was CD3-FITC.

\section{Results}

Three cycles of infection/cure results in protection

To establish the infection and cure model of C57BL/6 mice, animals were inoculated with infective $\mathrm{Spz}$ in the presence of $\mathrm{CQ}$ as described in the method section, referred to as infection/cure. Different dose and frequency regimens of infection/cure were compared (Table 1). Three groups of animals were challenged 4, 8 or 16 weeks post the last inoculation. Animals whose blood was negative for parasitaemia at 14 days post challenge were declared protected. One hundred percent of the animals that received three-inoculations of 20,000 $\mathrm{Spz}$ remained fully protected when challenged eight weeks post third inoculation, whereas those challenged 16 weeks post third inoculation exhibited only $40 \%$ protection (Figure 1). All animals treated with CQ (but not inoculated with $\mathrm{Spz}$ ) and challenged two weeks post suspension of the CQ treatment became parasitaemia confirming a lack of a residual protective effect of CQ following suspension of the drug. This data indicates infection/cure immunization with three, 20,000 Spz inoculations resulted in protection.

\section{Protection requires both CD8+ T cells and antibodies}

To investigate the relative role played by the cellular and humoral immune response in protection from the challenge, spleens and serum were collected from infection/ cure animals two weeks after suspension of CQ treatment and transferred into naive animals. Groups of 10 naïve C57BL/6 mice were given either splenocytes, serum or both as described in the methods section. Recipient animals were challenged $24 \mathrm{~h}$ post-transfer and parasitaemia monitored for two weeks. Ninety percent of the animals treated with both splenocytes and immune serum were protected. Animals that received splenocytes or immune serum alone showed $50 \%$ and $60 \%$ protection respectively (Figure 2A). This data points to an additive protective effect of cellular and humoral immunity. Having demonstrated that cellular immunity

Table 1 Immunization regimen with Spz used for infection/cure of mice (10 animals/group)

\begin{tabular}{ccc}
\hline Spz (dose) & Immunizations (n) & Protection (\%) \\
\hline 10,000 & 3 & 80 \\
20,000 & 2 & 40 \\
20,000 & 3 & 100 \\
\hline
\end{tabular}

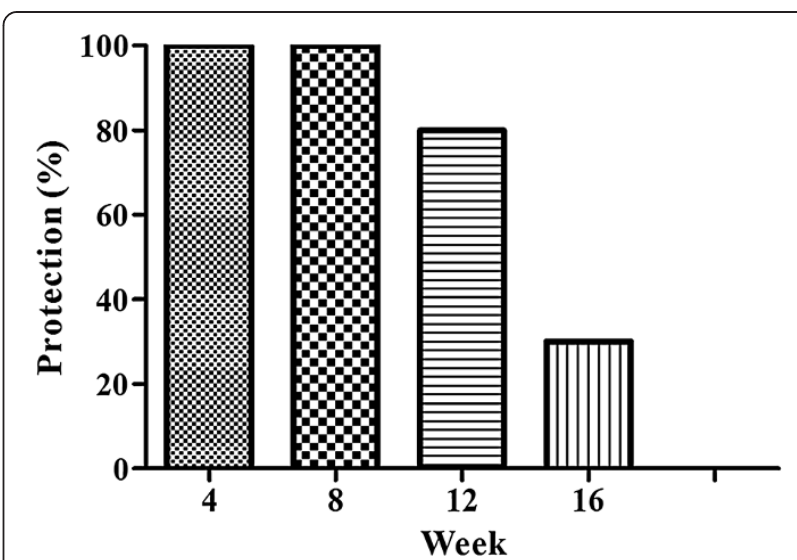

Figure 1 Infection with sporozoites under chloroquine cover induces long lasting protection. Infection with sporozoites under CQ cover induces long lasting protection. Three groups of ten mice each were inoculated three times, two weeks apart with 20,000 Spz. Each group of animals was challenged once with 1,000 sporozoites-at week 4, 8, 12 and 16 post the last inoculation as shown. For each group five naïve mice were used as infectivity controls. Appearance of parasitaemia was followed by Giemsa staining of blood smears.

was required to grant $100 \%$ protection, the role of $\mathrm{CD} 4+$ $\mathrm{T}$ cells and CD8+ T cells in protection using Ic-/- (MHC II $\mathrm{KO}, \mathrm{CD} 4+$ cell deficient) and $\beta 2$ microglobulin-/(MHC I KO, CD8 + cell deficient) mice was investigated. Immunized or non-immunized groups of $10 \mathrm{C} 57 \mathrm{BL} / 6$, $\mathrm{MHC}$ II $\mathrm{KO}$ or MHC I KO mice were challenged two weeks after suspension of the CQ treatment. As expected, wild type $\mathrm{C} 57 \mathrm{BL} / 6$ mice were fully protected whereas MHC II KO and MHC I KO animals were only partially protected (Figure 2B). These results indicate that CD8+ T cells are necessary for full protection and that production of protective antibodies is either CD4+ T helper cells dependent and/or lymphokines produced by CD4 cells contribute to the protection directly or by helping CD8+ T cells.

\section{The phenotype of infection/cure $P$. berghei responsive} CD8+ T cells is KLRG $1^{\text {high }} \mathrm{CD} 27^{\text {low }} \mathrm{CD} 44^{\text {high }}$ and CD62L low In order to identify the phenotype of CD8+ T cells generated during this infection/cure under CQ cover regimen, splenocytes and peripheral blood from mice three weeks post last inoculation for the presence of $\mathrm{CD} 8+, \mathrm{CD} 3+$, CD11a, CD127, CD27, KLRG1, CD44 and CD62L cells by flow cytometry was analysed. Circulating peripheral lymphocytes of infection/cure mice had about six-fold higher percent of CD8+ T cells containing KLRG1 ${ }^{\text {high }}, \mathrm{CD} 27^{\text {low }}$ compared to controls (Table 2) with p value of control group vs. infection/cure group at $<0.0001$. Figure 3 shows a representative experiment where splenocytes and peripheral blood lymphocytes were analysed. Analysis of the CD8+ KLRG1 $1^{\text {high }}, C D 27^{\text {low }}$ cell population had high expression of CD44 and low expression of CD62L (Figure 4). 

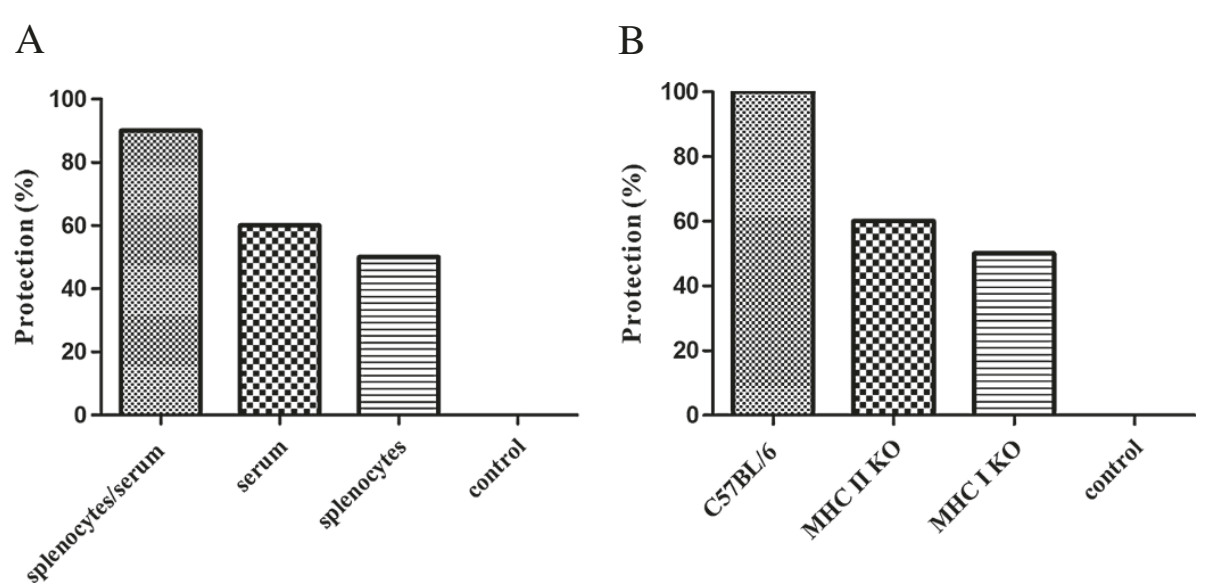

Figure 2 CD4+ T cells and CD8+ T cells are required for full protection. A) Infection/cure animals were sacrificed two weeks post suspension of CQ treatment. Splenocytes and/or serum from immunized or non-immunized animals were harvested and transferred into naïve C57BL/6 mice. Groups of ten recipient mice received $2 \times 10^{7}$ cells, $100 \mu \mathrm{L}$ serum or a combination of both. Twenty-four hours later animals were challenged with $1000 \mathrm{Spz}$ and appearance of parasitaemia was monitored for two weeks (representative of two experiments). B) Ten C57BL/6 wild type, or IC-/-(MHC II KO), or $\beta 2$ macroglobulin -/- (MHC I KO) were infected/cured under CQ cover as described, group of animals received $\mathrm{CQ}$ alone as a control ( results from one experiment). Two weeks post suspension of the CQ treatment animals were challenged with 1,000 Spz and the appearance of parasitaemia monitored for two weeks.

Infection/cure under CQ cover was thus associated with increased populations of effector memory CD8+ T cells. Results in Figures 3 and 4 are representative of three experiments with a pool of three spleens (splenocytes) or three experiments with 5-7 animals per group for the peripheral blood lymphocytes (peripheral blood). Statistical analysis for peripheral blood is reported in Table 2.

\section{Identifying $\mathrm{T}$ cell phenotype associated with protection}

To investigate whether the phenotype CD8+ KLRG1 ${ }^{\text {high }}$, $\mathrm{CD} 27^{\text {low }}, \mathrm{CD} 44^{\text {high }}, \mathrm{CD} 62 \mathrm{~L}^{\text {low }}$ is associated with protection, partial protection conferred by a two immunization regimen with 20,000 Spz (Table 1) was used. Twelve C57BL/6 mice were immunized twice with 20,000 Spz. For controls, three animals were injected with CQ only. Two weeks after suspension of CQ treatment, circulating peripheral blood was collected from individual mice. The presence of CD8+ KLRG1 $1^{\text {high }}, \mathrm{CD} 27^{\text {low }}$ cells was analysed. Animals were challenged and the appearance of parasitaemia monitored for two weeks. Expression of
KLRG1 ${ }^{\text {high }}, \mathrm{CD} 27^{\text {low }}$ was significantly higher in protected animals compared to non-protected or controls with a p-value of 0.0087 and 0.024 respectively (Table 3 ), suggesting that CD8+, KLRG1 $1^{\text {high }}, \mathrm{CD} 27^{\text {low }}, \mathrm{CD} 44^{\text {high }}$, CD62 $\mathrm{L}^{\text {low }}$ cells were associated with protection.

\section{Discussion}

Little progress has been made in elucidating the requirement for immune protection against malaria infection. Protection has not been achieved even with high titers of antibodies against known liver antigen [33], blood stage antigen $[34,35]$ or antigen specific CD8+ T cells produced with adenovirus immunization [36]. In addition, human immunization with irradiated sporozoites has shown limited success unless sporozoites are injected intravenously [37]. Conversely, immunization with irradiated sporozoites or live sporozoites under CQ cover induces protection $[29,31]$. In the current study, the infection/cure C57BL/6 mouse model was used to elucidate the immune protection conferred during malaria infection by characterizing

Table 2 CD8+ T cells containing KLRG $1^{\text {high }}, \mathrm{CD} 27^{\text {low }}$ phenotype

\begin{tabular}{|c|c|c|c|c|c|}
\hline \multirow[t]{2}{*}{ Group } & \multirow{2}{*}{$\begin{array}{l}\text { Mean CD8+ KLRG1 }{ }^{\text {high }} \\
\text { CD27 } \\
\text { low } \\
\text { cells }(\%)\end{array}$} & \multicolumn{2}{|c|}{$95 \% \mathrm{Cl}$ of mean } & \multirow{2}{*}{$\begin{array}{c}\text { Number of } \\
\text { lymphocytes/ } \\
\mathrm{ml} \times 10 \wedge 3\end{array}$} & \multirow{2}{*}{$\begin{array}{c}\text { Absolute number of } \\
\mathrm{CD}+\mathrm{KLRG} 1^{\text {high }}, \mathrm{CD} 27^{\text {low }} \\
\mathrm{T} \text { cells } \times 10^{\wedge} 3 / \mathrm{ml} \text { of blood }\end{array}$} \\
\hline & & Lower & Upper & & \\
\hline Control (15) & 1.04 & 0.73 & 1.36 & 15,409 & 160.168 \\
\hline Post-3 (22) & 5.72 & 4.41 & 7.04 & 14,894 & 841.32 \\
\hline Post-1 (5) & 1.30 & 0.95 & 1.64 & 16,518 & 214.147 \\
\hline
\end{tabular}

Infection/cure animals were inoculated three times (post-3) or one time with 20,000 Spz (post-1). The second column shows means of percent CD8+ cells expressing $\mathrm{KLRG}^{\text {high }}, \mathrm{CD} 27^{\text {low }}$ phenotype in the circulating peripheral lymphocytes. Statistical significance was determined using Mann Whitney test. The numbers of animals used in each experiment per group are shown in brackets. There was significant difference between the control vs. post- 3 groups ( $p<0.0001$ ) and between post- 3 vs. post- 1 $(p=0.0013)$. There was no significant difference between control vs. post- 1 groups. The last two columns show the number of CD8+ KLRG1 ${ }^{\text {high }}, C D 27^{\text {low }} T$ cell $\times 10 \wedge 3 / m l$ of blood. 


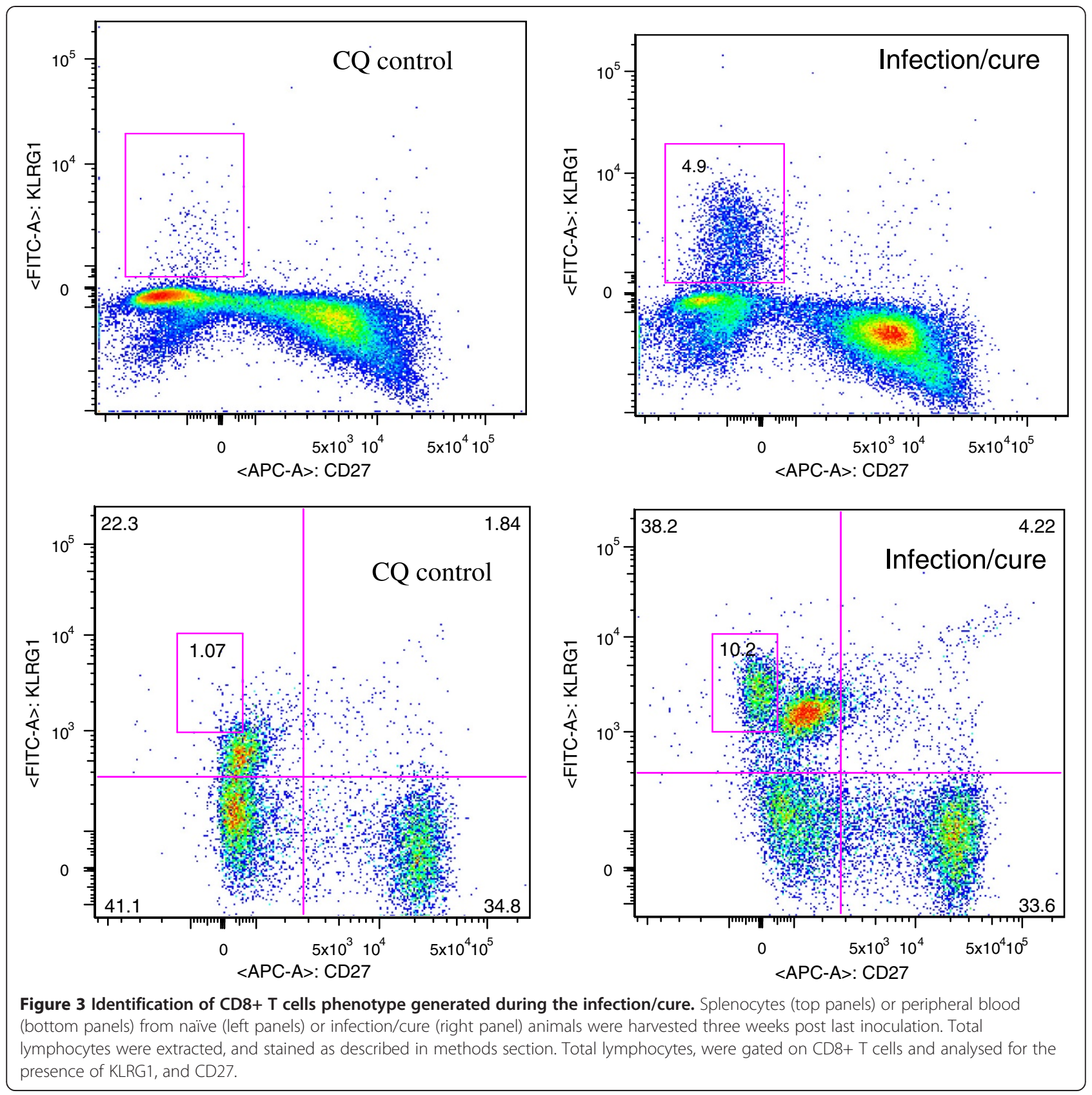

the nature of CD8+ T cells. Recent studies showed that both CD4+ T cells and CD8+ T cells are necessary to mediate immunity to liver stage malaria parasites [31,32]. This was demonstrated by immunizing BALB/c mice with Plasmodium yoelii iRBC under CQ cover and then treating with depleting antibodies against CD4+ $\mathrm{T}$ cells and CD8+ T cells. In this study, the infection/cure CD8+ T cells deficient (MHC I KO) mice resulted in only partial protection from lethal challenge, thus implicating CD8+ T cells in protection. Passive transfer with serum or cell alone also failed to confer $100 \%$ protection, thus indicating the cooperation of antigen specific cells and antibodies in granting protection. MHC II animals were also only partially protected. The most likely explanation is that the protective antibodies generated during infection/cure need CD4+ T cell help, which is lost in CD4+ T cell deficient animals. However, the role of CD4+ $\mathrm{T}$ cell in this model cannot be excluded is also to support the generation of protective CD8+ T cells or that they are directly involved in parasite killing. It will be interesting to perform transfer experiments to test the protective effect of serum from infection/cure MHC II animals enriched with CD4+ T cells from infection/cure wildtype animals. This will be important to discriminate between the roles of CD4+ T cells as 


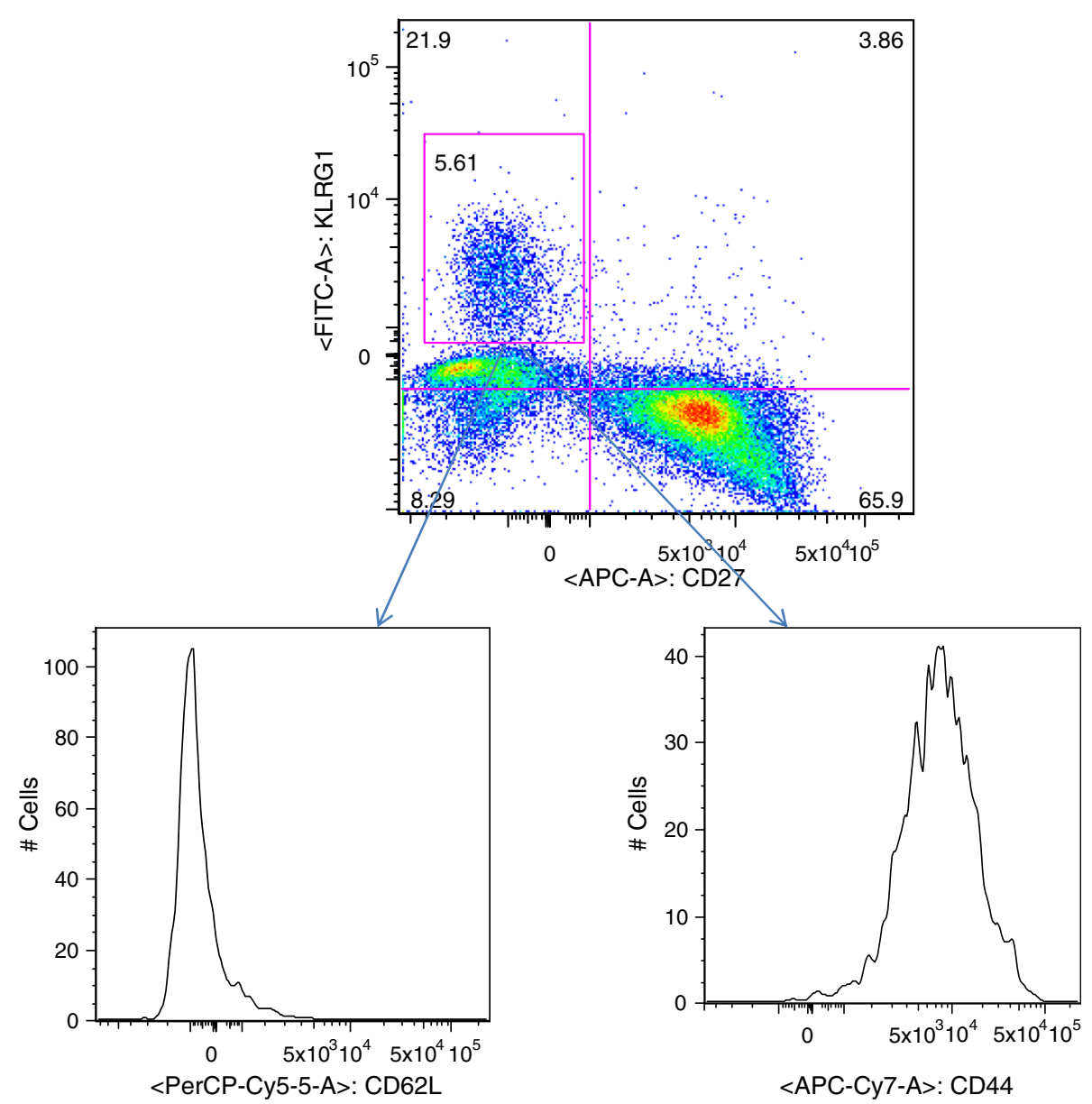

Figure 4 Identification of CD8+ T cells phenotype generated during the infection/cure. Splenocytes from infection/cure animals were gated on CD8+ KLRG1 ${ }^{\text {high }}, C D 27^{\text {low }}$ cells, and analysed for the level of expression of CD62L and CD44 experiments which were representative of 3 experiments with five mice in each group.

pure 'helper' for antibodies production or more direct involved in anti-plasmodium activity. From this study and that by Belnoue et al., data strongly suggest that both a humoral response and CD8+ T cells are required for immunity to liver stage $P$. berghei parasites [31,32].

Table 3 Mean CD8+ KLRG1 $1^{\text {high }}$, CD27 $7^{\text {low }}$ T cell (\%) expressed in circulating peripheral blood of control, protected and non-protected animals

\begin{tabular}{ccccc}
\hline Group & $\begin{array}{c}\text { Mean CD8+ KLRG1 } \\
\text { CD27 }\end{array}$ & cells (\%) & \multicolumn{2}{c}{$\mathbf{9 5 \%}$ Cl of mean } \\
\cline { 3 - 4 } & & Lower & Upper \\
\hline Control (3) & 1.117 & 0.3696 & 1.864 \\
Protected(6) & 5.772 & 3.759 & 7.785 \\
Non-protected (6) & 2.385 & 1.563 & 3.207 \\
\hline
\end{tabular}

Twelve C57BL/6 mice were immunized twice with 20,000 Spz. Six mice were protected and six were not protected. Statistical significance was determined using Mann Whitney test. The numbers of animals used in each group are shown in brackets. There was significant difference between the control vs. protected groups $(p=0.024)$ and protected vs. non-protected $(p=0.0087)$. There was a marginal significant difference between control vs. non-protected $(p=0.0476)$.
In an effort to further elucidate immune protection, $\mathrm{CD} 8+\mathrm{T}$ cells in peripheral blood and splenocytes were characterized. The distinct populations of $\mathrm{CD} 8+\mathrm{T}$ cells with phenotype $\mathrm{KLRG}^{\text {high }}, \mathrm{CD} 27^{\text {low }}, \mathrm{CD} 44^{\text {high }}, \mathrm{CD} 62 \mathrm{~L}^{\text {low }}$ were shown to be associated with protection. This population is absent in the intrahepatic lymphocytes. In the classical model of protection by immunization with irradiated sporozoites, the putative protective $\mathrm{CD} 8+\mathrm{T}$ cells are found mostly in the liver $[18,19]$ and produce IFN $\gamma$. In a recent study, Nganou-Makandop et al. [21] reported comparable levels of hepatic CD8+ T cells with a CD44 ${ }^{\text {high }}$, $\mathrm{CD}_{62} \mathrm{~L}^{\text {low }}$ phenotype that produce IFNY in response to PMA/Iono. In this study, mice were either immunized with radiation-attenuated sporozoites or infected with $P$. berghei under CQ cover. In the current study, the $\mathrm{CD} 8+\mathrm{KLRG} 1^{\text {high }}, \mathrm{CD} 27^{\text {low }}, \mathrm{CD} 44^{\text {high }}, \mathrm{CD} 62 \mathrm{~L}^{\text {low }}$ phenotype that was associated with protection was not present in the liver of immunized animals. A possible explanation of the apparent discrepancy is that more than one population of $\mathrm{CD} 8+\mathrm{T}$ cells contributes to protection. One can 
speculate that the splenic CD8+KLRG1 $1^{\text {high }}, \mathrm{CD} 27^{\text {low }}$, $\mathrm{CD} 44^{\text {high }}, \mathrm{CD} 62 \mathrm{~L}^{\text {low }}$ cells and the intrahepatic CD8+ $\mathrm{CD} 44^{\text {high }}, \mathrm{CD} 62 \mathrm{~L}^{\text {low }}$ cells are the same antigen specific population whose phenotype and organ-homing is modulated by antigen exposure. In explorative experiments, it was observed that splenic and peripheral blood CD8+ $\mathrm{KLRG}_{1}^{\text {high }}, \mathrm{CD} 27^{\text {low }}, \mathrm{CD} 44^{\text {high }}, \mathrm{CD} 62 \mathrm{~L}^{\text {low }} \mathrm{T}$ cells respond to in vitro stimulation with anti CD3 and in vivo sporozoites infection by producing IFNg (see Additional file 1: Figure S1 and Figure S2). This is consistent with CD8+ $\mathrm{KLRG}^{\text {high }}, \mathrm{CD} 27^{\text {low }}, \mathrm{CD} 44^{\text {high }}, \mathrm{CD} 62 \mathrm{~L}^{\text {low }} \mathrm{T}$ cells participating to protection by producing IFNg. However, these cells do not account for all the IFNg produced in response to in vitro stimulation with anti CD3 (see Additional file 1: Figure S1 and Figure S2), or in vivo stimulation with sporozoites see Additional file 1: Figure S1 and Figure S2). It is, therefore, conceivable that other CD8+ T cells with low expression of KLRG1 are generated during this infection/ cure regimen. Such cells respond to sporozoite infection with IFNg production and display an elevated ability to respond to $\mathrm{T}$ cell receptor triggered by releasing IFNg. The role of this $\mathrm{CD} 8+\mathrm{T}$ cell phenotype in protection remains to be determined. KLRG1 has been shown to down regulate $\mathrm{T}$ cell receptor signaling $[38,39]$, thus suggesting that the acquisition of the KLRG1 ${ }^{\text {high }}$ phenotype is important for effector memory population after antigen encounter and execution of effector function.

\section{Conclusions}

KLRG1 $1^{\text {high }}, \mathrm{CD} 27^{\text {low }}, \mathrm{CD} 44^{\text {high }}, \mathrm{CD} 62 \mathrm{~L}^{\text {low }}$ are the circulating $\mathrm{CD} 8+\mathrm{T}$ cells generated during infection which are associated with protection and thus represent a correlate of protection. Passive transfer of purified/enriched KLRG1 $1^{\text {high }}, \mathrm{CD}_{2} 7^{\text {low }}, \mathrm{CD} 44^{\text {high }}, \mathrm{CD} 62 \mathrm{~L}^{\text {low }} \mathrm{CD} 8+\mathrm{T}$ cells will be critical in demonstrating a direct correlation of this phenotype in protection.

\section{Additional file}

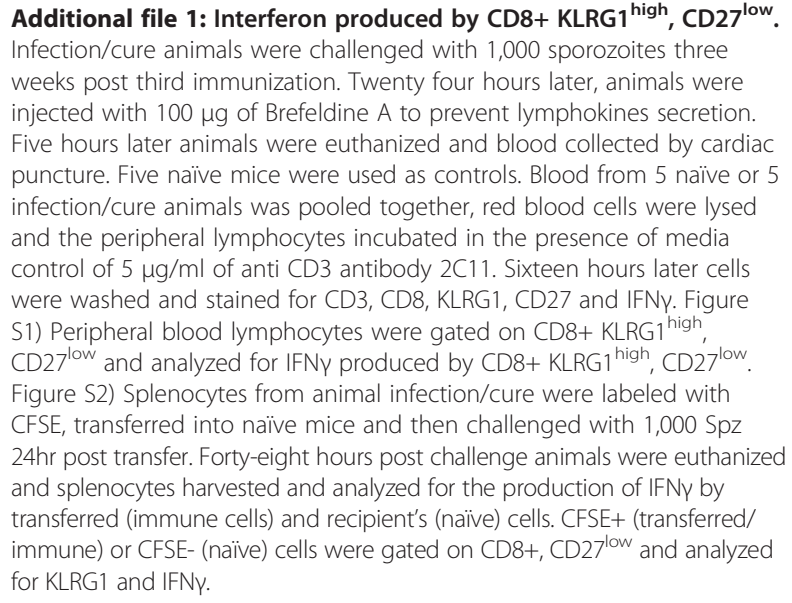

Competing interests

The authors declare that they have no competing interests.

\section{Authors' contributions}

Conceived and designed the experiments: EK, CB, CFO. Performed the experiments: CB, EK. Analysed the data: CB, EK. Provided reagents and support: CFO, JM. Wrote the Manuscript: EK, CB. Reviewed the Manuscript: CFO, JHR. All authors approved the final version of the manuscript.

\section{Acknowledgments}

Material has been reviewed by the Walter Reed Army Institute of Research. There is no objection to its presentation and/or publication. The opinions or assertions contained herein are the private views of the author, and are not to be construed as official, or as reflecting true views of the Department of the Army or the Department of Defense. Research was conducted in compliance with the Animal Welfare Act and other federal statutes and regulations relating to animals and experiments involving animals and adheres to principles stated in the Guide for the Care and Use of Laboratory Animals, NRC Publication, 1996 edition.

\section{Author details}

'Military Malaria Research Program, Malaria Vaccine Branch, Walter Reed Army Institute of Research, 503 Robert Grant Ave, Silver Spring, MD 20910 USA. ${ }^{2}$ Entomology Branch, Walter Reed Army Institute of Research, 503 Robert Grant Ave, Silver Spring, MD 20910, USA.

Received: 12 September 2013 Accepted: 2 February 2014 Published: 12 March 2014

\section{References}

1. WHO: World Malaria Report 2011. Geneva: World Health Organization; 2011. http://www.who.int/malaria/world_malaria_report_2011/en/.

2. The malERA Consultative Group on Vaccines: A research agenda for malaria eradication: vaccines. PLoS Med 2011, 8:e1000398.

3. Marsh K, Kinyanjui S: Immune effector mechanisms in malaria. Parasite Immunol 2006, 28:51-60.

4. Achtman AH, Bull PC, Stephens R, Langhorne J: Longevity of the immune response and memory to blood-stage malaria infection. Curr Top Microbiol Immunol 2005, 297:71-102

5. Migot F, Chougnet C, Raharimalala L, Astagneau P, Lepers JP, Deloron P: Human immune responses to the Plasmodium falciparum ring-infected erythrocyte surface antigen [Pf155/RESA] after a decrease in malaria transmission in Madagascar. Am J Trop Med Hyg 1993, 48:432-439.

6. Wipasa J, Okell L, Sakkhachornphop S, Suphavilai C, Chawansuntati K, Liewsaree W, Hafalla JC, Riley EM: Short-lived IFN-gamma effector responses, but long-lived IL-10 memory responses, to malaria in an area of low malaria endemicity. PLoS Pathog 2011, 7:e1001281.

7. Zevering $Y$, Khamboonruang $C$, Rungruengthanakit $K$, Tungviboonchai $L$, Ruengpipattanapan J, Bathurst I, Barr P, Good MF: Life-spans of human T-cell responses to determinants from the circumsporozoite proteins of Plasmodium falciparum and Plasmodium vivax. Proc Natl Acad Sci U S A 1994, 91:6118-6122.

8. Bejon P, Mwacharo J, Kai O, Todryk S, Keating S, Lowe B, Lang T, Mwang TW, Gilbert SC, Peshu N, Marsh K, Hill AV: The induction and persistence of T cell IFN-gamma responses after vaccination or natural exposure is suppressed by Plasmodium falciparum. J Immunol 2007, 179:4193-4201.

9. Dent AE, Chelimo K, Sumba PO, Spring MD, Crabb BS, Moormann AM, Tisch DJ, Kazura JW: Temporal stability of naturally acquired immunity to merozoite surface protein-1 in Kenyan adults. Malar J 2009, 8:162.

10. Flanagan KL, Mwangi T, Plebanski M, Odhiambo K, Ross A, Sheu E, Kortok M, Lowe B, Marsh K, Hill AV: Ex-vivo interferon-gamma immune response to thrombospondin-related adhesive protein in coastal Kenyans: longevity and risk of Plasmodium falciparum infection. Am J Trop Med Hyg 2003, 68:421-430.

11. Hviid L, Theander TG, Jakobsen PH, Bu-Zeid YA, Abdulhadi NH, Saeed BO, Jepsen S, Bayoumi RA, Bendtzen K, Jensen JB: Cell-mediated immune responses to soluble Plasmodium falciparum antigens in residents from an area of unstable malaria transmission in the Sudan. APMIS 1990, 98:594-604

12. Crompton PD, Pierce SK, Miller LH: Advances and challenges in malaria vaccine development. J Clin Invest 2010, 120:4168-4178. 
13. Guilbride DL, Gawlinski P, Guilbride PD: Why functional pre-erythrocytic and bloodstage malaria vaccines fail: a meta-analysis of fully protective immunizations and novel immunological model. PLoS One 2010, 5:e10685.

14. Nussenzweig RS, Vanderberg J, Most H, Orton C: Protective immunity produced by the injection of $x$-irradiated sporozoites of plasmodium berghei. Nature 1967, 216:160-162

15. Mueller AK, Labaied M, Kappe SH, Matuschewski K: Genetically modified Plasmodium parasites as a protective experimental malaria vaccine. Nature 2005, 433:164-167.

16. Gwadz RW, Cochrane AH, Nussenzweig V, Nussenzweig RS: Preliminary studies on vaccination of rhesus monkeys with irradiated sporozoites of Plasmodium knowlesi and characterization of surface antigens of these parasites. Bull World Health Organ 1979, 57(Suppl 1):165-173.

17. Hoffman SL, Goh LM, Luke TC, Schneider I, Le TP, Doolan DL, Sacci J, de la Vega P, Dowler M, Paul C, Gordon DM, Stoute JA, Church LW, Sedegah M, Heppner DG, Ballou WR, Richie TL: Protection of humans against malaria by immunization with radiation-attenuated Plasmodium falciparum sporozoites. J Infect Dis 2002, 185:1155-1164.

18. Krzych U, Schwenk J: The dissection of CD8 T cells during liver-stage infection. Curr Top Microbiol Immunol 2005, 297:1-24.

19. Berenzon D, Schwenk RJ, Letellier L, Guebre-Xabier M, Williams J, Krzych U: Protracted protection to Plasmodium berghei malaria is linked to functionally and phenotypically heterogeneous liver memory CD8+ T cells. J Immuno/ 2003, 171:2024-2034.

20. Weiss WR, Sedegah M, Beaudoin RL, Miller LH, Good MF: CD8+ T cells [cytotoxic/suppressors] are required for protection in mice immunized with malaria sporozoites. Proc Natl Acad Sci U S A 1988, 85:573-576.

21. Nganou-Makamdop K, van Gemert GJ, Arens T, Hermsen CC, Sauerwein RW: Long term protection after immunization with $P$. berghei sporozoites correlates with sustained IFNy responses of hepatic CD8+ memory T cells. PLoS One 2012, 7:e36508.

22. Guebre-Xabier M, Schwenk R, Krzych U: Memory phenotype CD8[+] T cells persist in livers of mice protected against malaria by immunization with attenuated Plasmodium berghei sporozoites. Eur J Immunol 1999, 29:3978-3986

23. Jobe O, Lumsden J, Mueller AK, Williams J, Silva-Rivera H, Kappe SH, Schwenk RJ, Matuschewski K, Krzych U: Genetically attenuated Plasmodium berghei liver stages induce sterile protracted protection that is mediated by major histocompatibility complex Class I-dependent interferongamma-producing CD8+ T cells. J Infect Dis 2007, 196:599-607.

24. Schofield L, Villaquiran J, Ferreira A, Schellekens $H$, Nussenzweig R, Nussenzweig V: Gamma interferon, CD8+ T cells and antibodies required for immunity to malaria sporozoites. Nature 1987, 330:664-666.

25. Sayles PC, Wassom DL: Immunoregulation in murine malaria, Susceptibility of inbred mice to infection with Plasmodium yoelii depends on the dynamic interplay of host and parasite genes. J Immunol 1988, 141:241-248.

26. Chen G, Feng H, Liu J, Qi ZM, Wu Y, Guo SY, Li DM, Wang JC, Cao YM: Characterization of immune responses to single or mixed infections with $P$. yoelii $17 \mathrm{XL}$ and $P$. chabaudi AS in different strains of mice. Parasitol Int 2010, 59:400-406

27. Beaudoin RL, Strome CP, Mitchell F, Tubergen TA: Plasmodium berghei: immunization of mice against the ANKA strain using the unaltered sporozoite as an antigen. Exp Parasitol 1977, 42:1-5.

28. Meuwissen JH, Golenser J, Verhave JP: Development of effective antisporozoite immunity by natural bites of Plasmodium-berghei-infected mosquitoes in rats under prophylactic treatment with various drug regimens. Isr J Med Sci 1978, 14:601-605.

29. Roestenberg M, McCall M, Hopman J, Wiersma J, Luty AJ, van Gemert GJ, van de Vegte-Bolmer M, van Schaijk B, Teelen K, Arens T, Spaarman L, de Mast Q, Roeffen W, Snounou G, Rénia L, van der Ven A, Hermsen CC, Sauerwein R: Protection against a malaria challenge by sporozoite inoculation. N Engl J Med 2009, 361:468-477.

30. Roestenberg M, Teirlinck AC, McCall MB, Teelen K, Makamdop KN, Wiersma J, Arens T, Beckers P, van Gemert G, van de Vegte-Bolmer M, van der Ven AJ, Luty AJ, Hermsen CC, Sauerwein RW: Long-term protection against malaria after experimental sporozoite inoculation: an open-label follow-up study. Lancet 2011, 377:1770-1776.

31. Belnoue $E$, Costa FT, Frankenberg $T$, Vigario AM, Voza $T$, Leroy $N$, Rodrigues MM, Landau I, Snounou G, Rénia L: Protective T cell immunity against malaria liver stage after vaccination with live sporozoites under chloroquine treatment. J Immuno/ 2004, 172:2487-2495.
32. Belnoue E, Voza T, Costa FTM, Gruner AC, Mauduit M, Rosa DS, Depinay N, Kayibanda M, Vigário AM, Mazier D, Snounou G, Sinnis P, Rénia L: Vaccination with live Plasmodium yoelii blood stage parasites under chloroquine cover induces cross-stage immunity against malaria liver stage. J Immunol 2008, 181:8552-8558.

33. Cummings JF, Spring MD, Schwenk RJ, Ockenhouse CF, Kester KE, Polhemus ME, Walsh DS, Yoon IK, Prosperi C, Juompan LY, Lanar DE, Krzych U, Hall BT, Ware LA, Stewart VA, Williams J, Dowler M, Nielsen RK, Hillier CJ, Giersing BK, Dubovsky F, Malkin E, Tucker K, Dubois MC, Cohen JD, Ballou WR, Heppner DG Jr: Recombinant Liver Stage Antigen-1 [LSA-1] formulated with AS01 or AS02 is safe, elicits high titer antibody and induces IFN-gamma/IL-2 CD4+ T cells but does not protect against experimental Plasmodium falciparum infection. Vaccine 2010, 28:5135-5144.

34. Polhemus ME, Magill AJ, Cummings JF, Kester KE, Ockenhouse CF, Lanar DE, Dutta S, Barbosa A, Soisson L, Diggs CL, Robinson SA, Haynes JD, Stewart VA, Ware LA, Brando C, Krzych U, Bowden RA, Cohen JD, Dubois MC, Ofori-Anyinam O, De-Kock E, Ballou WR, Heppner DG Jr: Phase I dose escalation safety and immunogenicity trial of Plasmodium falciparum apical membrane protein [AMA-1] FMP2.1, adjuvanted with ASO2A, in malaria-naive adults at the Walter Reed Army Institute of Research. Vaccine 2007, 25:4203-4212.

35. Sheehy SH, Duncan CJ, Elias SC, Biswas S, Collins KA, O'Hara GA, Halstead FD, Ewer KJ, Mahungu T, Spencer AJ, Miura K, Poulton ID, Dicks MD, Edwards NJ, Berrie E, Moyle S, Colloca S, Cortese R, Gantlett K, Long CA, Lawrie AM, Gilbert SC, Doherty T, Nicosia A, Hill AV, Draper SJ: Phase la clinical evaluation of the safety and immunogenicity of the Plasmodium falciparum blood-stage antigen AMA1 in ChAd63 and MVA vaccine vectors. PLOS ONE 2012, 7:e31208.

36. Forbes EK, Biswas S, Collins KA, Gilbert SC, Hill AV, Draper SJ: Combining liver- and blood-stage malaria viral-vectored vaccines: investigating mechanisms of CD8+ T cell interference. J Immunol 2011, 187:3738-3750.

37. Epstein JE, Tewari K, Lyke KE, Sim BK, Billingsley PF, Laurens MB, Gunasekera A, Chakravarty S, James ER, Sedegah M, Richman A, Velmurugan S, Reyes S, Li M, Tucker K, Ahumada A, Ruben AJ, Li T, Stafford R, Eappen AG, Tamminga C, Bennett JW, Ockenhouse CF, Murphy JR, Komisar J, Thomas N, Loyevsky M, Birkett A, Plowe CV, Loucq C, Edelman R, Richie TL, Seder RA, Hoffman SL: Live attenuated malaria vaccine designed to protect through hepatic $\mathrm{CD}^{+} \mathrm{T}$ cell immunity. Science 2011, 334:475-480.

38. Wilson DC, Matthews S, Yap GS: IL-12 signaling drives CD8+ T cell IFN-gamma production and differentiation of KLRG1+ effector subpopulations during Toxoplasma gondii Infection. J Immunol 2008, 180:5935-5945.

39. Beyersdorf NB, Ding X, Karp K, Hanke T: Expression of inhibitory 'killer cell lectin-like receptor $\mathrm{G} 1^{\prime}$ identifies unique subpopulations of effector and memory CD8 T cells. Eur J Immunol 2001, 31:3443-3452.

\section{doi:10.1186/1475-2875-13-92}

Cite this article as: Brando et al:: Phenotypic characterization of Plasmodium berghei responsive CD8+ T cells after immunization with live sporozoites under chloroquine cover. Malaria Journal 2014 13:92.

\section{Submit your next manuscript to BioMed Central and take full advantage of:}

- Convenient online submission

- Thorough peer review

- No space constraints or color figure charges

- Immediate publication on acceptance

- Inclusion in PubMed, CAS, Scopus and Google Scholar

- Research which is freely available for redistribution 